\title{
A RARE PEDIATRIC CASE OF CHRONIC ARSENIC POISONING FROM AYURVEDIC MEDICATION
}

\author{
MANDYAM DHATI RAVI' ${ }^{\text {, TIRIN BABU }}{ }^{2}$, GEORGE MATHEW PANACHIYIL ${ }^{2}$, JUNY SEBASTIAN ${ }^{2 *}$
}

${ }^{1}$ Department of Paediatrics, JSS Medical College and Hospital, JSS Academy of Higher Education and Research, Mysuru, Karnataka, India. ${ }^{2}$ Department of Pharmacy Practice, JSS College of Pharmacy, JSS Academy of Higher Education and Research, Mysuru, Karnataka, India. Email: junysebastian@jssuni.edu.in

Received: 02 March 2020, Revised and Accepted: 09 April 2020

\begin{abstract}
Ayurveda is an indigenous system of medicine becoming more popular around the world in recent years. In various Ayurvedic formulations, the arsenical compounds are intentionally added as the main active ingredients or as an auxiliary agent to assist the efficacy of herbal drugs. The chronic arsenic poisoning following the use of Ayurvedic medication is reported rarely in the literature. This report describes a rare pediatric case of chronic arsenic poisoning from Ayurvedic medication in a 15-year-old girl. She was a known case of seizure disorder and was on treatment with Ayurvedic medication for 1 year. The generalized hyperpigmentation and thickening of soles were noticed in the girl 7 months after taking the herbal tablet. The plasma-coupled atomic absorption spectroscopy of herbal tablet was performed in a laboratory and the result showed 4.3 mg of arsenic present in each herbal tablet. The patient was advised to stop the Ayurvedic medication and as an alternate drug, tablet levetiracetam (250 mg, twice a day) was started for the treatment of seizure disorder. During the follow-up, her cutaneous manifestations improved and is doing well.
\end{abstract}

Keywords: Pediatric patient, Ayurvedic medication, Chronic arsenic poisoning, Hyperpigmentation, Anemia.

(C) 2020 The Authors. Published by Innovare Academic Sciences Pvt Ltd. This is an open access article under the CC BY license (http://creativecommons. org/licenses/by/4. 0/) DOI: http://dx.doi.org/10.22159/ajpcr.2020.v13i6.37437

\section{INTRODUCTION}

Ayurveda is an Indian traditional system of medicine and is based on herbal products preparations [1]. It is practiced commonly in Southeast Asia and various parts of the world [1]. However, Ayurvedic preparations often include toxic heavy metals and other elements as part of the Rasa Shastra practice [2]. These elements are used purposefully, as Ayurvedic tradition holds that lead, mercury, copper, gold, iron, silver, tin, and zinc may aid to restore good health and normal function to the human body [2].

There has been increased number of case reports being published of toxic metals poisoning such as lead, mercury, and arsenic after the use of Ayurveda remedies which created a negative impact on the public for the use of Ayurvedic medicine [3]. The arsenical compounds have a remarkable history of pharmacological utilities and traditional practices [3]. Therefore, it has been used in the management of asthma, psoriasis, leukemia, syphilis, epilepsy, and as an aphrodisiac [4,5]. In various Ayurvedic formulations, the arsenical compounds are intentionally added as the main active ingredients or as an auxiliary agent to assist the efficacy of herbal drugs [6]. The chronic arsenic poisoning following the use of Ayurvedic medication is reported rarely in the literature. Our case highlights the possibility of chronic arsenic poisoning following the long-term administration of Ayurvedic medication.

\section{CASE REPORT}

A 15-year-old girl was admitted to the pediatric department of the hospital with the complaints of fever with chills which were insidious in onset and reduced with medication (tablet paracetamol $500 \mathrm{mg}$, thrice daily) and cough for 3 days. She also complained of the generalized hyperpigmentation and thickening of soles for 3 months. She was a known case of seizure disorder and was on treatment with Ayurvedic medication (two herbal tablets in the morning and one herbal tablet at night) for 1 year. She had one episode of the seizure (GTCS type) 3 weeks back. The generalized hyperpigmentation and thickening of soles were noticed in the girl 7 months after taking the herbal tablet. She had no other medical problems and was not taking any other medications. There was no history of similar illness in the family or neighborhood.
On general examination, the vitals were normal and pallor was present. She had hyperpigmentation of nipples, knuckles, soles, gingiva, and nails. Black patch on tongue and callosities were also noticed (Fig. 1). Systemic examinations were normal. Laboratory investigations revealed low hemoglobin $(9 \mathrm{mg} / \mathrm{dl})$, serum ferritin $(6.36 \mathrm{ng} / \mathrm{ml})$, and iron (28.6 ug/dl) levels. Reticulocyte count was elevated to $3.2 \%$. Vitamin B-12 level test, LDH tests, urine routine test, thyroid function tests, liver function tests, and renal function tests were normal. Peripheral blood smear was microcytic hypochromic anemia with leukopenia. CT scan of the brain was found to be normal.

The Ayurvedic medication was suspected to contain arsenic based on the evidence from the literature. The quantitative analysis of herbal tablet was performed in a laboratory for the detection of arsenic using plasma-coupled atomic absorption spectroscopy. The result showed $4.3 \mathrm{mg}$ of arsenic present in each herbal tablet. The patient was taking two herbal tablets in the morning and one herbal at night per day from the past 1 year. Hence, she had taken a total of $12.9 \mathrm{mg}$ of arsenic per day. The diagnosis was made as chronic arsenic poisoning from Ayurvedic medication. This case showed a probable relationship between Ayurvedic medication administration and chronic arsenic poisoning on the Naranjo Scale with a score of 7.

The patient was advised to stop the Ayurvedic medication and as an alternate drug, tablet levetiracetam (250 mg, twice a day) was started for the treatment of seizure disorder. During the course in the hospital, the patient was managed conservatively with maintenance IV fluids, tablet paracetamol (500 mg, twice daily), and one stat dose of albendazole. Iron and folic acid tablets were also administered in view of anemia. The patient was discharged after 4 days of hospital stay and was advised to continue levetiracetam, iron, and folic acid tablets. During the follow-up, her cutaneous manifestations improved and are doing well (Fig. 2).

\section{DISCUSSION}

The word arsenic is originated from arsenikon (Greek word) meaning potent [3]. Many efficacy aspects and side effects of arsenical compounds used in Ayurveda are mentioned in classical texts of Ayurveda and 


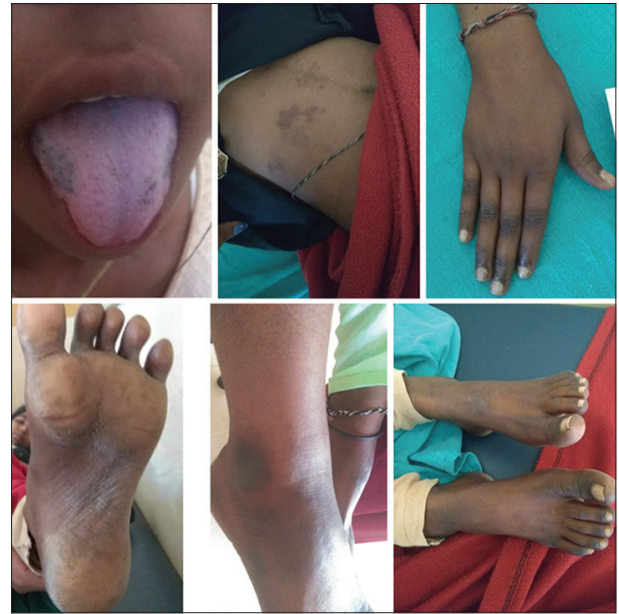

Fig. 1: Erythematous maculopapular rash over the anterior aspect of knee and forearm

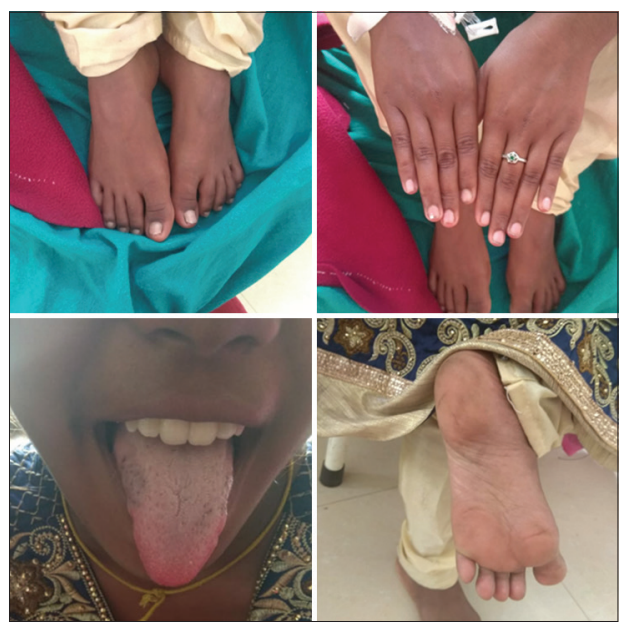

Fig. 2: Follow-up images

modern literature [3]. Of the 22 Ayurveda products purchased in India, $41 \%$ contained arsenic [7].

A quantity of $12 \mu \mathrm{g}$ arsenic is expected to be the safe amount which can be handled by the human body per day. The maximal permissible concentration of arsenic in drinking water is $10 \mu \mathrm{g} / \mathrm{L}$ as suggested by the World Health Organization. The permissible level of arsenic in Ayurveda with herbal ingredients should be $<10 \mathrm{mg} / \mathrm{L}$ according to the department of AYUSH (Ayurveda, Yoga, and Naturopathy, Unani, Siddha, and Homeopathy) in the year 2005 [6]. Saper et al. study measured lead, $\mathrm{Hg}$, and As in Ayurvedic medications and found one-fifth had levels of at least one of these over above permissible limits [8].

Arsenic poisoning can be acute or chronic type and it presents with multisystem involvement [9]. The specific cutaneous manifestations of chronic arsenic poisoning are pigmentations and keratosis [10]. Chronic arsenic poisoning also results in several systemic manifestations and the important ones being chronic lung disease, liver disease, and other diseases such as polyneuropathy, peripheral vascular disease, hypertension, ischemic heart disease, diabetes mellitus, non-pitting edema of feet/hands, weakness, and anemia [10]. Cancer of skin, lung, and urinary bladder are important cancers related with chronic arsenic poisoning [10-12]. Management of chronic arsenic poisoning comprises avoiding further exposure followed by symptomatic treatment and chelation therapy [1].

In Khandpur et al. case report, an 11-year-old girl developed manifestations of arsenical keratosis and non-cirrhotic portal hypertension after 6 and 18 months intake of Ayurvedic medications which were prescribed for the treatment of epilepsy. Arsenic content in Ayurvedic medicines taken by the child ranged from $5 \mathrm{mg} / \mathrm{L}$ to $248 \mathrm{mg} / \mathrm{L}$. The serum arsenic level in the girl after chronic arsenic poisoning was found to be $202.20 \mu \mathrm{g} / \mathrm{L}$ (normal $<60 \mu \mathrm{g} / \mathrm{L}$ ). Cutaneous manifestations of the girl in his report improved after the withdrawal of Ayurvedic medications [6]. Pinto et al. reported three patients presented with chronic arsenic poisoning following prolonged Ayurvedic medication use. Their diagnosis was confirmed by high arsenic levels in the blood, urine, hair, and nails and also in the Ayurvedic drug consumed by two patients. Discontinuation of the Ayurvedic drugs followed by treatment with D-penicillamine resulted in blood arsenic levels returned to normal with clinical recovery in all of them [1]

\section{LEARNING POINTS}

1. Ayurvedic medications should be consumed under strict guidance and supervision of qualified medical practitioners to prevent serious adverse health effects.

2. Health-care professionals should be aware of the development of chronic arsenic poisoning following the administration of Ayurvedic medications and should also recognize the early signs of toxicity. So that prompt intervention can be undertaken.

\section{ACKNOWLEDGMENTS}

The authors would like to thank the staffs and the postgraduate students of the Department of Paediatrics and Department of Clinical Pharmacy, JSS Hospital, Mysuru, for their support and encouragement.

\section{AUTHORS' CONTRIBUTIONS}

Dr. Mandyam Dhati Ravi treating doctor provided the clinical details of the case and reviewed the manuscript, Dr. Tirin Babu and Dr. George Mathew Panachiyil were involved in the preparation, reviewing, and editing of the manuscript, and Dr. Juny Sebastian was involved in the organizing, reviewing, and editing of the manuscript.

\section{CONFLICTS OF INTEREST}

The authors declare no conflicts of interest.

\section{AUTHORS' FUNDING}

Nil.

\section{ETHICAL STATEMENT}

Ethical approval was not applicable for case report in our institution.

\section{REFERENCES}

1. Pinto B, Goyal P, Flora SJ, Gill KD, Singh S. Chronic arsenic poisoning following ayurvedic medication. J Med Toxicol 2014;10:395-8.

2. Mikulski MA, Wichman MD, Simmons DL, Pham AN, Clottey V, Fuortes LJ. Toxic metals in ayurvedic preparations from a public health lead poisoning cluster investigation. Int J Occup Med Environ Health 2017;23:187-92.

3. Panda AK, Hazra J. Arsenical compoundsin ayurveda medicine: A prospective analysis. Int J Res Ayurveda Pharm 2012;3:772-6.

4. Schwartz RA. Arsenic and the skin. Int J Dermatol 1997:36:241-50

5. Prasad HR, Malhotra AK, Hanna N, Kochupillai V, Atri SK, Ray R, et al. Arsenicosis from homeopathic medicines: A growing concern. Clin Exp Dermatol 2006;31:497-8.

6. Khandpur S, Malhotra AK, Bhatia V, Gupta S, Sharma VK, Mishra R, et al. Chronic arsenic toxicity from ayurvedic medicines. Int J Dermatol 2008;47:618-21.

7. McElvaine MD, Harder EM, Johnson L, Baer RD, Satzger RD. Lead poisoning from the use of Indian folk medicines. JAMA 1990;264:2212-3.

8. Saper RB, Phillips RS, Sehgal A, Khouri N, Davis RB, Paquin J, et al. Lead, mercury, and arsenic in US-and Indian-manufactured ayurvedic medicines sold via the internet. JAMA 2008;300:915-23.

9. Sharma S, Gupta A, Deshmukh A, Puri V. Arsenic poisoning and Mees' lines. QJM 2016;109:565-6. 
10. Mazumder DG. Chronic arsenic toxicity and human health. Indian J Med Res 2008;128:436-47.

11. Prakash NU, Deepa S, Sripriya N, Bhuvaneswari S. Quality assessment for the presence of heavy metals in herbal materials from the markets of
Chennai, India. Int J Pharm Pharm Sci 2014;6:574-8.

12. Bandyopadhyay D, Ghosh D, Chattopadhyay A, Mitra E. Curry leaves as alternative medicine in heavy metal induced occupational health hazards. Int J Pharm Pharm Sci 2016;8:8-20. 